\title{
Thermal analysis and vibrational spectroscopic characterization of the boro silicate mineral datolite $-\mathrm{CaBSiO}_{4}(\mathrm{OH})$
}

\author{
Ray L. Frost ${ }^{\mathrm{a}, *}$, Yunfei Xi ${ }^{\mathrm{a}}$, Ricardo Scholz ${ }^{\mathrm{b}}$, Rosa Malena Fernandes Lima ${ }^{\mathrm{c}}$, Laura Frota Campos Horta ${ }^{\mathrm{b}}$, \\ Andres Lopez ${ }^{\text {a }}$

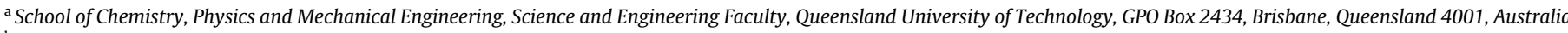 \\ ${ }^{\mathrm{b}}$ Geology Department, School of Mines, Federal University of Ouro Preto, Campus Morro do Cruzeiro, Ouro Preto, MG 35,400-000, Brazil \\ ${ }^{\mathrm{c}}$ Mining Engineering Department, School of Mines, Federal University of Ouro Preto, Campus Morro do Cruzeiro, Ouro Preto, MG 35,400-00, Brazil
}

\section{H I G H L I G H T S}

- In this work we have studied datolite $\mathrm{CaBSiO}_{4}(\mathrm{OH})$.

- It is an important mineral used for the production of special ceramics.

- For the immobilization of mediumlevel radioactive wastes.

- We have characterized datolite using vibrational spectroscopy.

- The spectra are in accordance with $\mathrm{BO}^{\prime}(\mathrm{OH})$ and $\mathrm{SiO}$ tetrahedra.

\section{A R T I C L E I N F O}

\section{Article history:}

Received 11 February 2013

Received in revised form 29 May 2013

Accepted 4 June 2013

Available online 28 June 2013

\section{Keywords:}

Thermal analysis

Thermal stability

Datolite

Silicate

Borate

Vibrational spectroscopy
G R A P H I C A L A B S T R A C T

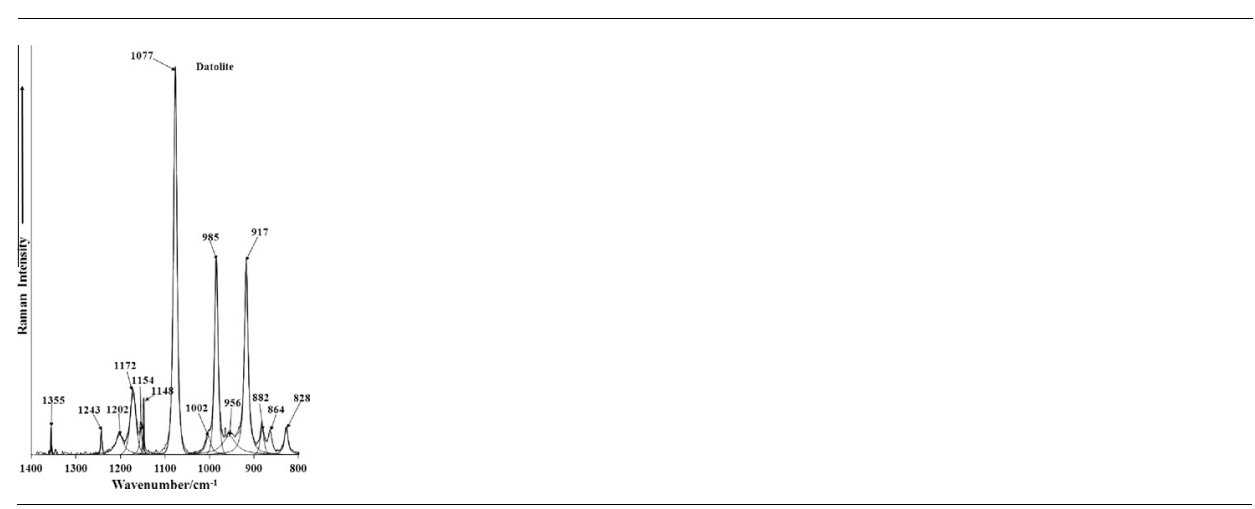

The objective of this work is to determine the thermal stability and vibrational spectra of datolite CaB$\mathrm{SiO}_{4}(\mathrm{OH})$ and relate these properties to the structure of the mineral. The thermal analysis of datolite shows a mass loss of $5.83 \%$ over a $700-775^{\circ} \mathrm{C}$ temperature range. This mass loss corresponds to 1 water $\left(\mathrm{H}_{2} \mathrm{O}\right)$ molecules $p f u$. A quantitative chemical analysis using electron probe was undertaken. The Raman spectrum of datolite is characterized by bands at 917 and $1077 \mathrm{~cm}^{-1}$ assigned to the symmetric stretching modes of BO and SiO tetrahedra. A very intense Raman band is observed at $3498 \mathrm{~cm}^{-1}$ assigned to the stretching vibration of the $\mathrm{OH}$ units in the structure of datolite. $\mathrm{BOH}$ out-of-plane vibrations are characterized by the infrared band at $782 \mathrm{~cm}^{-1}$. The vibrational spectra are based upon the structure of datolite based on sheets of four- and eight-membered rings of alternating $\mathrm{SiO}_{4}$ and $\mathrm{BO}_{3}(\mathrm{OH})$ tetrahedra with the sheets bonded together by calcium atoms.

(c) 2013 Elsevier B.V. All rights reserved.

\section{Introduction}

Borates and boron silicate minerals such as boracite, ulexite, colemanite and datolite are important materials for the production of boron compounds that are used in the manufacture of a variety of industrial products. The mineral datolite is a calcium borate silicate and has chemical formula given as $\mathrm{CaBSiO}_{4}(\mathrm{OH})$. It has

\footnotetext{
* Corresponding author. Tel.: +61 73138 2407; fax: +61 731381804 .

E-mail address: r.frost@qut.edu.au (R.L. Frost).
}

special application as a raw material in the glass industry and in the production of special ceramics used to immobilize medium-level radioactive wastes for disposal [1] and to protect from neutron radiation [2]. Other uses are in the electrical engineering [3-5] in the microfiltration processes of waste and natural water [6] and in the protection of metals [7]. With minor importance, datolite is used as a gemstone [8]. Datolite is an important mineral used for the production of special ceramics for the immobilization of medium-level radioactive wastes. Datolite is sought by mineral collectors market due to the beauty of the crystals. 
Datolite was first described by Klaproth [9] in samples from Nødebro Iron Mine, Aust-Agder, Norway. The crystal structure was first determined by Ito and Mori [10] and later was refined by Foit et al., [11]. The mineral crystallizes in the monoclinic system, space group $P 2_{1} / c, Z=4$, with cell parameters given as $a=4.832 \AA, b=7.608 \AA, c=9.636 \AA$ and $\beta=90.40^{\circ}$. Refinement of the structure has continued [12-14]. Datolite is member of the gadolinite-datolite group that includes gadolinite, minasgeraisite and bakerite among others [15]. As determined by Ito and Mori [10], the structure of datolite is based on sheets of four- and eight-membered rings of alternating $\mathrm{SiO}_{4}$ and $\mathrm{BO}_{3}(\mathrm{OH})$ tetrahedra with the sheets bonded together by calcium atoms. bridging oxygen atoms are bonded to one $\mathrm{Si}$, one $\mathrm{B}$, and one or two Ca atoms; whereas the non-bridging oxygens atoms are bonded either to one $\mathrm{Si}$ and two $\mathrm{Ca}$ or to one $\mathrm{B}$, one $\mathrm{H}$, and two $\mathrm{Ca}$ atoms.

Datolite is commonly found in cavities and veins, especially in basalts and gabbros [16] and more rarely in granitic rocks [17,18]. Datolite is considered a low temperature mineral formed by hydrothermal activity $[17,19]$. In this work, spectroscopic investigation of a pure datolite sample from Italy has been carried out. The analysis includes spectroscopic characterization of the structure with infrared and Raman spectroscopy. Electron microprobe in the WDS mode was applied in the chemical analysis and was used to support the mineral characterization. Thermogravimetric analysis was applied to support the $\mathrm{H}_{2} \mathrm{O}$ determination and the formula calculation.

\section{Experimental}

\section{Samples description and preparation}

The datolite sample studied in this work was obtained from the collection of the Geology Department of the Federal University of Ouro Preto, Minas Gerais, Brazil, with sample code SAA-128. The sample is from Canossa, Reggio Emilia, Italy, where it occurs filling fractures in basaltic rocks.

The sample was gently crushed and the associated minerals were removed under a stereomicroscope Leica MZ4. The datolite single crystals were selected and phase analyzed by X-ray diffraction. Scanning electron microscopy (SEM) was to study the morphology of the mineral.

\section{Electron microprobe analysis (EMP)}

Chemical characterization was carried via EMP. One single crystal was selected and prepared in epoxy resin. The single crystal was analyzed with the performance of ten spots. The chemical analysis was carried out with a Jeol JXA8900R spectrometer from the Physics Department of the Federal University of Minas Gerais, Belo Horizonte. For each selected element, we used the following standards and crystals: $\mathrm{Ca}$ - anorthite/PETJ, Si - quartz/PETJ, K - microcline/ PETJ, $\mathrm{Na}$ - jadeite/TAP, $\mathrm{Al}-\mathrm{Al}_{2} \mathrm{O}_{3} / \mathrm{TAP}, \mathrm{Fe}$ - siderite/LIF and $\mathrm{F}$ $\mathrm{CaF}_{2}$. B was calculated by stoichiometry and $\mathrm{H}_{2} \mathrm{O}$ was calculated by mass loss with thermogravimetric analysis. The epoxy embedded datolite sample was coated with a thin layer of evaporated carbon. The electron probe microanalysis in the WDS (wavelength dispersive spectrometer) mode was obtained at $15 \mathrm{kV}$ accelerating voltage and beam current of $10 \mathrm{nA}$. Chemical formula was calculated on the basis of five oxygen atoms $(\mathrm{O}, \mathrm{F}, \mathrm{OH})$. ZAF correction was applied with support of the JEOL software XM-97312. The error in measurements is considered $\pm 2 \mathrm{wt}$.\%.

\section{Raman microprobe spectroscopy}

Non-oriented crystals of datolite were placed on a polished metal surface on the stage of an Olympus BHSM microscope, equipped with $10 \times, 20 \times$, and $50 \times$ objectives. The microscope is part of a Renishaw 1000 Raman microscope system, which also includes a monochromator, a filter system and a CCD detector (1024 pixels). The Raman spectra were excited by a Spectra-Physics model 127 He-Ne laser producing highly polarized light at $633 \mathrm{~nm}$ and collected at a nominal resolution of $2 \mathrm{~cm}^{-1}$ and a precision of $\pm 1 \mathrm{~cm}^{-1}$ in the range between 100 and $4000 \mathrm{~cm}^{-1}$. Repeated acquisitions on the crystals using the highest magnification $(50 \times)$ were accumulated to improve the signal to noise ratio of the spectra. Raman Spectra were calibrated using the $520.5 \mathrm{~cm}^{-1}$ line of a silicon wafer. The Raman spectrum of at least 10 crystals was collected to ensure the consistency of the spectra.

\section{Infrared spectroscopy}

Infrared spectra were obtained using a Nicolet Nexus 870 FTIR spectrometer with a smart endurance single bounce diamond ATR cell. Spectra over the $4000-525 \mathrm{~cm}^{-1}$ range were obtained by the co-addition of 128 scans with a resolution of $4 \mathrm{~cm}^{-1}$ and a mirror velocity of $0.6329 \mathrm{~cm} / \mathrm{s}$. Spectra were co-added to improve the signal to noise ratio.

Spectral manipulation such as baseline correction/adjustment and smoothing were performed using the Spectracalc software package GRAMS (Galactic Industries Corporation, NH, USA). Band component analysis was undertaken using the Jandel 'Peakfit' software package that enabled the type of fitting function to be selected and allows specific parameters to be fixed or varied accordingly. Band fitting was done using a Lorentzian-Gaussian cross-product function with the minimum number of component bands used for the fitting process. The Gaussian-Lorentzian ratio was maintained at values greater than 0.7 and fitting was undertaken until reproducible results were obtained with squared correlations of $r^{2}$ greater than 0.995 .

\section{Thermogravimetric analysis - TG/DTG}

Thermogravimetric analysis of the datolite mineral were obtained by using TA Instruments Inc. Q50 high-resolution TGA operating at a $10^{\circ} \mathrm{C} / \mathrm{min}$ ramp with data sample interval of $0.50 \mathrm{~s} / \mathrm{pt}$ from room temperature to $1000{ }^{\circ} \mathrm{C}$ in a high-purity flowing nitrogen atmosphere $\left(100 \mathrm{~cm}^{3} / \mathrm{min}\right)$. A total mass of $101.95 \mathrm{mg}$ of finely ground dried sample was heated in an open platinum crucible.

\section{Results and discussion}

\section{Thermal data and chemical characterization}

Differential thermal analysis (DTA) and thermogravimetric (TG) and DTG measurements were carried out simultaneously. The TG curve (Fig. 1) of datolite shows a total mass loss of around $5.83 \%$ on heating. TG data indicate a mass loss in a temperature range between $700{ }^{\circ} \mathrm{C}$ and $775^{\circ} \mathrm{C}$. The DTG curve shows one main maxima, at about $749.5^{\circ} \mathrm{C}$ due to loosely bound water molecules. The total mass loss of $5.83 \%$ corresponds to 1 water $\left(\mathrm{H}_{2} \mathrm{O}+\mathrm{F}\right)$ molecules $p f u$. As described by Tarney et al. [20], the thermal transformation of datolite in $\mathrm{O}_{2}$ atmosphere consists in the production of a boroncontaining analogue of the melilite structure, composition $\mathrm{Ca}_{2} \mathrm{SiB}_{2-}$ $\mathrm{O}_{7}$ in accordance with the following reaction:

$2 \mathrm{CaBSiO}_{4}(\mathrm{OH}) \rightarrow \mathrm{H}_{2} \mathrm{O}+\mathrm{Ca}_{2} \mathrm{SiB}_{2} \mathrm{O}_{7}+\mathrm{SiO}_{2}$

A study of the thermal analysis and infrared spectrum of datolite was also described by Perchiazzi et al. [14]. These authors reported the relationship between bakerite and datolite. 


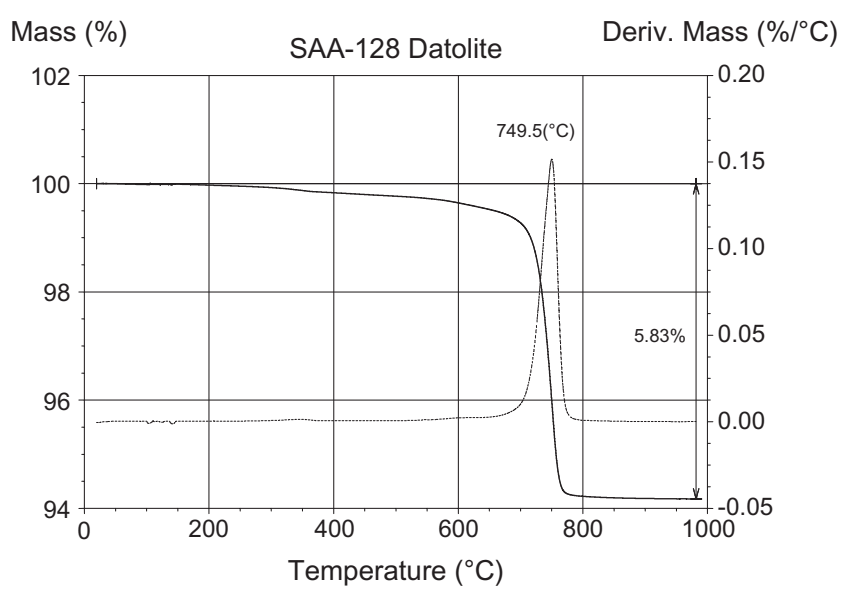

Fig. 1. TG/DTG pattern of datolite.

\section{Chemical analysis}

The quantitative chemical analysis of datolite is presented in Table 1 . The composition was calculated as mean values in ten spots. The range of the chemical analysis is also presented, and shows no significant variance. The analytical accuracy can be considered as $2 \%$. The chemical formula was calculated on the basis of 5 oxygen atoms $(\mathrm{O}, \mathrm{OH}, \mathrm{F})$ in the structure. The chemical composition indicates a pure mineral phase, with $\mathrm{Si}$ and $\mathrm{Ca}$ as the major constituents in addition to B calculated by stoichiometry and $\mathrm{H}_{2} \mathrm{O}$ calculated by loss of mass via thermogravimetric analysis. The total loss of mass of $5.83 \%$ is considered to be the sum of $\mathrm{H}_{2} \mathrm{O}$ (5.75\%) and $\mathrm{F}$ content $(0.08 \%)$. The results show traces of $\mathrm{K}, \mathrm{Na}, \mathrm{Al}$ and $\mathrm{Fe}$, which replaces partially $\mathrm{Ca}$ and $\mathrm{Si}$. The chemical formula of the studied sample can be expressed as: $\mathrm{CaB}_{1.02}\left(\mathrm{Si}_{0.98} \mathrm{O}_{4}\right)\left(\mathrm{OH}_{0.99}, \mathrm{~F}_{0.01}\right)$. The chemical formula shows nearly ideal composition. The $\mathrm{F}$ content is not significant.

\section{Spectroscopy}

The Raman spectrum of datolite in the $100-4000 \mathrm{~cm}^{-1}$ spectral range is reported in Fig. 2a. This spectrum illustrates the relative intensity of the bands and their band positions. Large parts of the spectrum show little or no intensity and the spectrum is therefore, subdivided into sections based upon the types of vibration being observed. Likewise, the infrared spectrum shown in Fig. $2 \mathrm{~b}$ is subdivided into sections.

The Raman spectrum of datolite in the $800-1400 \mathrm{~cm}^{-1}$ spectral region is reported in Fig. 3a. Sharp intense Raman bands are observed. The Raman band at $917 \mathrm{~cm}^{-1}$ is assigned to the BO symmetric stretching mode of boron in the tetrahedral structure, whereas the Raman band at $985 \mathrm{~cm}^{-1}$ is attributed to the $\mathrm{BO}$ antisymmetric stretching mode. The intense Raman band at $1077 \mathrm{~cm}^{-1}$ is assigned to the SiO stretching vibration of tetrahedral silicon in the datolite environment. The series of bands at 1148 $1154,1172,1202$ and $1243 \mathrm{~cm}^{-1}$ are associated with the SiO antisymmetric stretching modes. An alternative description may be in terms of $\mathrm{BOH}$ in-plane bending modes, the band position of which is expected to be in the $1000-1300 \mathrm{~cm}^{-1}$ spectral range. It is noted that some density functional calculations have been undertaken [21]. However, whenever $\mathrm{OH}$ units and/or water units are involved in the structure then DFT calculations have proven very difficult. The problem resides with the exact position of the hydrogen atom.

In comparison with the Raman spectrum, the infrared spectrum in the 500-1300 spectral range is illustrated in Fig. 3b. The IR spectral profile is complex to say the least, with a number of overlapping component bands. The spectrum consists of overlapping bands which are attributed to the $\mathrm{BO}$ and $\mathrm{SiO}$ symmetric and antisymmetric stretching modes. The infrared bands centered upon $782 \mathrm{~cm}^{-1}$ with shoulder bands at 750,771 and $789 \mathrm{~cm}^{-1}$ are due to BOH out of plane bending modes. Ross in Farmer's treatise tabulated the spectral range of various vibrational modes (Table 1 VIII) [22]. Ross defined the spectra regions for various bands for trigonal and tetrahedral boron. As Ross rightly points out the spectra of borate minerals depends heavily on the possible anions in the mineral [22]. The coordination polyhedron around the boron atom will be either a triangle or a tetrahedron. In the case of datolite, the structure consists of linked borate triangles and tetrahedra. Thus for datolite the vibrational spectra of both structural units will be observed. The spectra of datolite are complex especially in the infrared spectrum. This is caused by the observation of bands due to four different coordination polyhedra namely $\mathrm{BO}_{3}^{3-}, \mathrm{B}(\mathrm{OH})_{3}$, $\mathrm{BO}_{4}^{5-}$, and $\mathrm{B}(\mathrm{OH})_{4}$. In the case of datolite, the recurring unit is $\mathrm{BO}_{3}(\mathrm{OH})$.

The Raman spectra of datolite in the $300-800 \mathrm{~cm}^{-1}$ spectral range and in the $100-300 \mathrm{~cm}^{-1}$ spectral range are shown in Fig. $4 \mathrm{a}$ and $\mathrm{b}$. The first spectrum is dominated by an intense Raman band at $693 \mathrm{~cm}^{-1}$. This band is ascribed to the BO symmetric stretching mode of tetrahedral boron. A second Raman band is observed at $669 \mathrm{~cm}^{-1}$ which is also assigned to this band. The Raman band at $392 \mathrm{~cm}^{-1}$ is attributed to $\mathrm{CaO}$ stretching vibration. A number of bands are observed in the far low wavenumber region. An intense band is found at $165 \mathrm{~cm}^{-1}$. One possible assignment is to OCaO bending modes.

The Raman spectrum of datolite in the $2600-3800 \mathrm{~cm}^{-1} \mathrm{spec}-$ tral range is shown in Fig. 5a and the infrared spectrum over the $2600-3600 \mathrm{~cm}^{-1}$ spectral range is given in Fig. 5b. The Raman spectrum displays a single sharp band at $3498 \mathrm{~cm}^{-1}$. This band is assigned to the stretching vibration of the datolite $\mathrm{OH}$ units. The infrared spectrum displays a sharp band at $3491 \mathrm{~cm}^{-1}$ with a shoulder band at $3484 \mathrm{~cm}^{-1}$. The infrared spectrum has a long tail

Table 1

Chemical composition of datolite Canossa, Reggio Emilia, Italy (mean of 10 electron microprobe analyses). $\mathrm{B}_{2} \mathrm{O}_{3}$ calculated by stoichiometry and $\mathrm{H}_{2} \mathrm{O}$ calculated by mass loss via thermogravimetric analysis.

\begin{tabular}{|c|c|c|c|c|}
\hline Constituent & wt.\% & Range (wt.\%) & Number of atoms & Probe standard/crystal \\
\hline $\mathrm{SiO}_{2}$ & 36.17 & $35.02-36.69$ & 0.98 & Quartz/PETJ \\
\hline $\mathrm{CaO}$ & 34.46 & $34.05-35.05$ & 1.00 & Anortite/PETJ \\
\hline $\mathrm{B}_{2} \mathrm{O}_{3}$ & 21.76 & Calculated by stoichiometry & 1.02 & \\
\hline $\mathrm{K}_{2} \mathrm{O}$ & 0.01 & $0.00-0.02$ & 0.00 & Microcline/PETJ \\
\hline $\mathrm{Na}_{2} \mathrm{O}$ & 0.01 & $0.00-0.04$ & 0.00 & Jadeite/TAP \\
\hline $\mathrm{Al}_{2} \mathrm{O}_{3}$ & 0.02 & $0.01-0.04$ & 0.00 & $\mathrm{Al}_{2} \mathrm{O}_{3} / \mathrm{TAP}$ \\
\hline $\mathrm{FeO}$ & 0.02 & $0.00-0.08$ & 0.00 & Siderite/LIF \\
\hline $\mathrm{H}_{2} \mathrm{O}$ & 5.75 & Calculated by mass loss (TG) & 0.99 & \\
\hline $\mathrm{F}$ & 0.08 & $0.00-0.24$ & 0.01 & $\mathrm{CaF}_{2} / \mathrm{TAP}$ \\
\hline Total & 98.28 & & 4.00 & \\
\hline
\end{tabular}




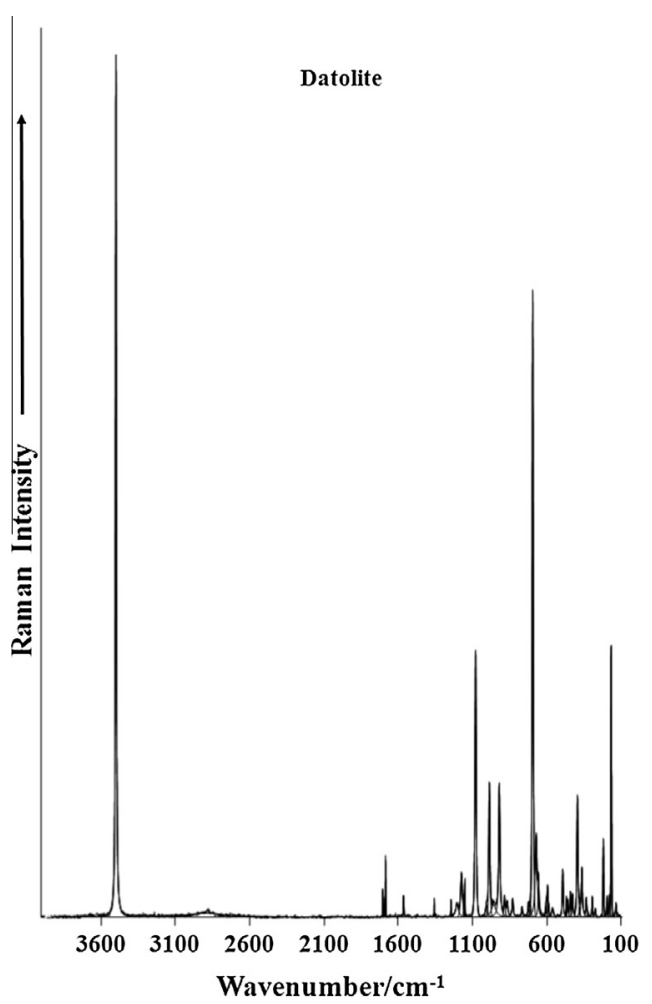

(a)

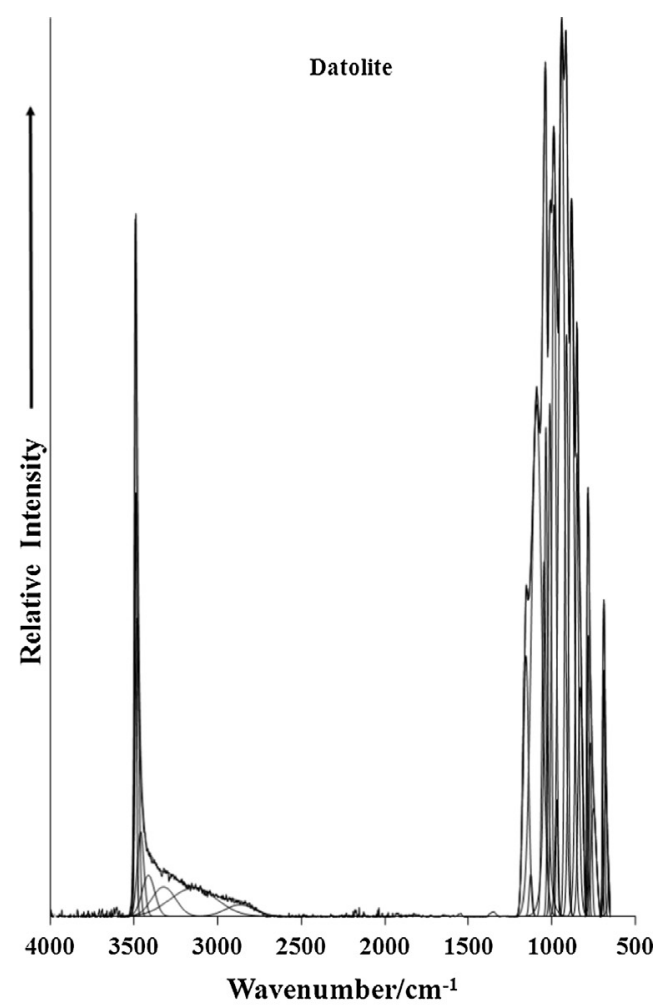

(b)

Fig. 2. (a) Raman spectrum of datolite over the $100-4000 \mathrm{~cm}^{-1}$ spectral range and (b) Infrared spectrum of datolite over the $500-4000 \mathrm{~cm}-1$ spectral range.

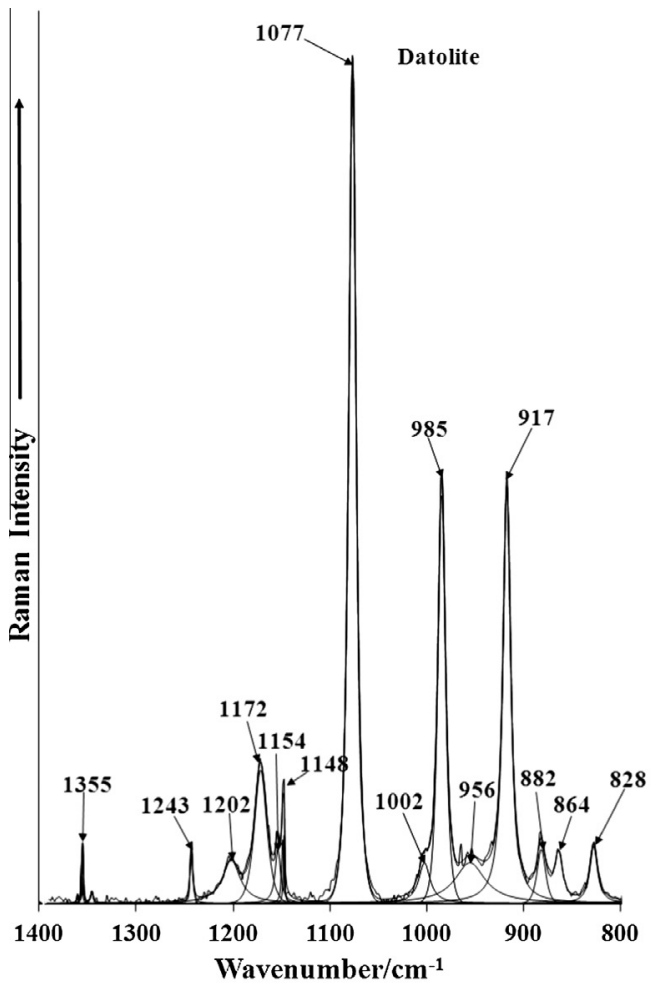

(a)

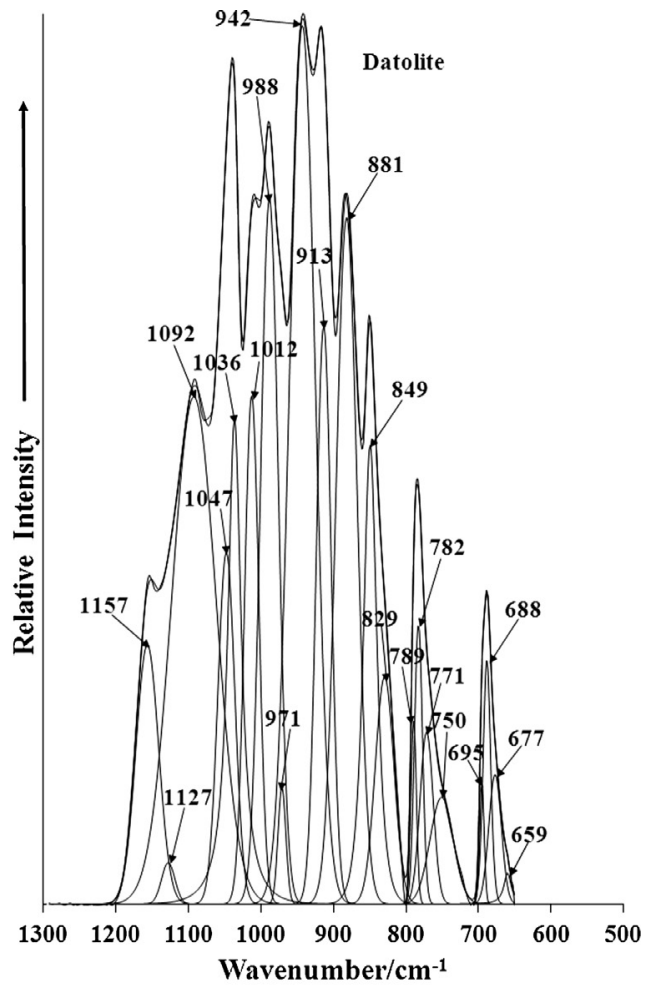

(b)

Fig. 3. (a) Raman spectrum of datolite over the $800-1400 \mathrm{~cm}^{-1}$ spectral range and (b) Infrared spectrum of datolite over the $500-1300 \mathrm{~cm}^{-1}$ spectral range. 


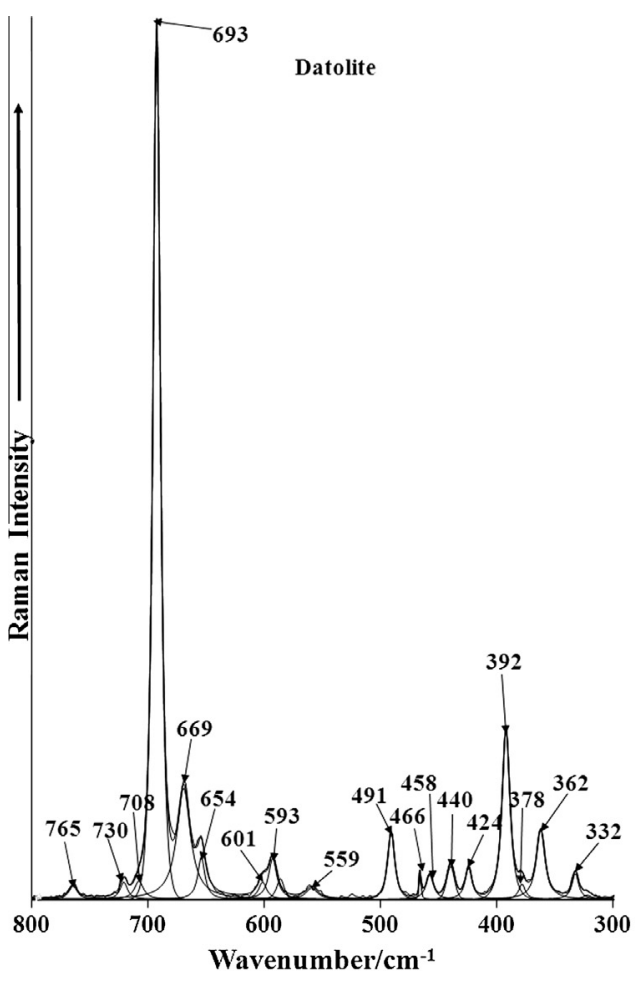

(a)

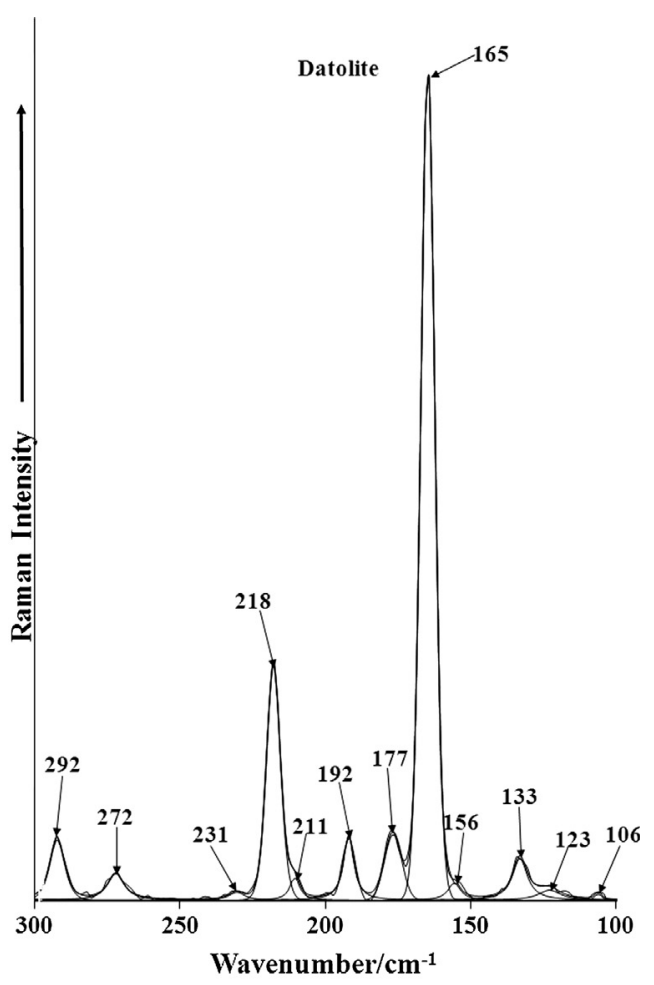

(b)

Fig. 4. (a) Raman spectrum of datolite over the $300-800 \mathrm{~cm}^{-1}$ spectral range and (b) Raman spectrum of datolite over the $100-300 \mathrm{~cm}^{-1} \mathrm{spectral}$ range.

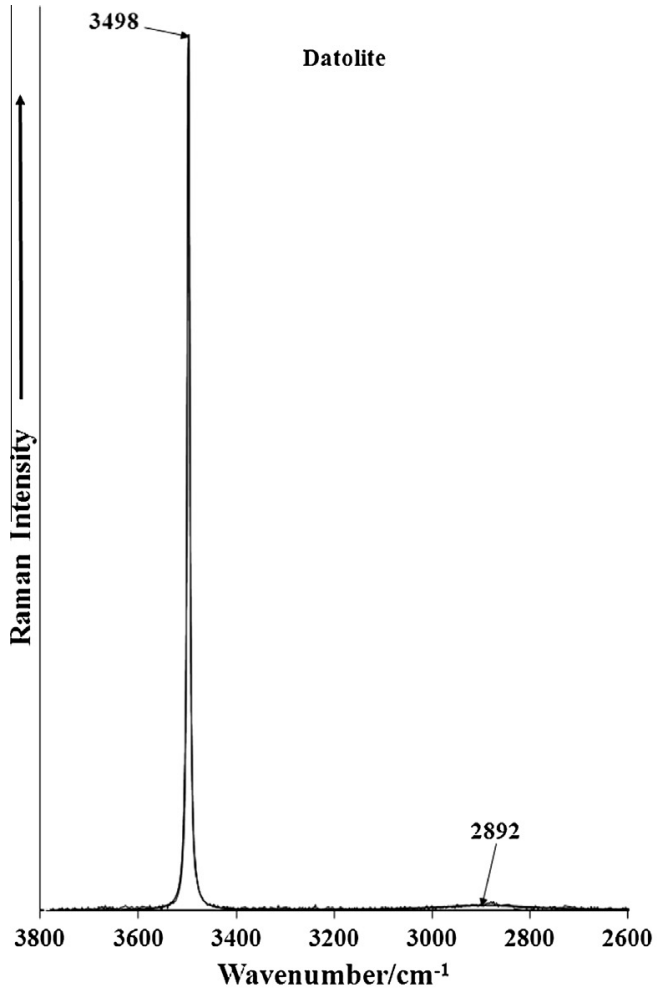

(a)

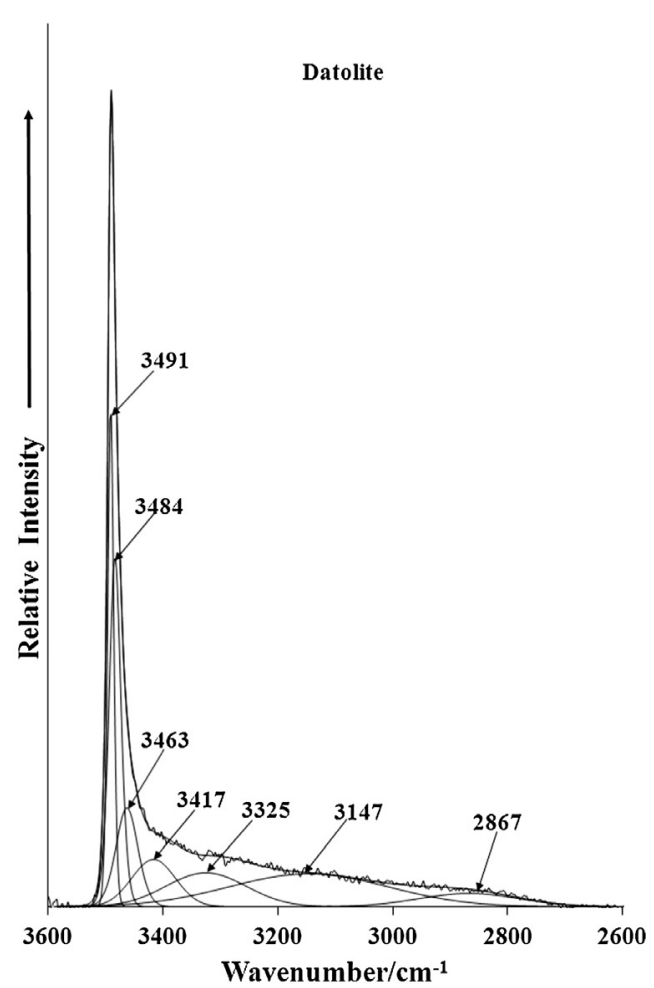

(b)

Fig. 5. (a) Raman spectrum of datolite over the $2600-4000 \mathrm{~cm}^{-1}$ spectral range and (b) Infrared spectrum of datolite over the $2600-4000 \mathrm{~cm}^{-1}$ spectral range. 
and bands may be resolved at 2867, 3147, 3325, 3417 and $3463 \mathrm{~cm}^{-1}$. It is interesting to compare the Raman spectrum of datolite with that of ameghinite $\mathrm{NaB}_{3} \mathrm{O}_{3}(\mathrm{OH})_{4}$. Raman bands for ameghinite are observed at 3203, 3249 and $3385 \mathrm{~cm}^{-1}$. These bands are assigned to the symmetric stretching vibrations of the $\mathrm{OH}$ units. For datolite, the hydrogen bonds are bifurcated. This birfurcation contributes to the complexity of the spectrum in the $\mathrm{OH}$ stretching region.

\section{Conclusions}

The mineral datolite $\mathrm{CaBSiO}_{4}(\mathrm{OH})$ is an important mineral as it is used to make glass for the uptake of radioactive nuclides and is useful for the disposal of radioactive waste. As such it is important to know the thermal stability of the mineral. The mineral decomposes at $749.5{ }^{\circ} \mathrm{C}$ with a mass loss of $5.83 \%$. This mass loss corresponds to 1 water molecule per formula unit.

The chemical reaction is $2 \mathrm{CaBSiO}_{4}(\mathrm{OH})$

$\rightarrow \mathrm{H}_{2} \mathrm{O}+\mathrm{Ca}_{2} \mathrm{SiB}_{2} \mathrm{O}_{7}+\mathrm{SiO}_{2}$

The quantitative chemical analysis determined by EMP/WDS shows a relatively simple composition and no significant substitutions were observed. The chemical formula can be expressed as $\mathrm{CaB}_{1.02}\left(\mathrm{Si}_{0.98} \mathrm{O}_{4}\right)\left(\mathrm{OH}_{0.99}, \mathrm{~F}_{0.01}\right)$. We have studied the mineral datolite using vibrational spectroscopy and the spectra reflect the structure of datolite which is based on sheets of four- and eight-membered rings of alternating $\mathrm{SiO}_{4}$ and $\mathrm{BO}_{3}(\mathrm{OH})$ tetrahedra with the sheets bonded together by calcium atoms. Raman and infrared bands of the borate and silicate tetrahedra are observed. A very intense Raman band at $3498 \mathrm{~cm}^{-1}$ is assigned to the $\mathrm{OH}$ stretching vibration of the $\mathrm{OH}$ units.

\section{Acknowledgements}

The financial and infra-structure support of the Discipline of Nanotechnology and Molecular Science, Science and Engineering Faculty of the Queensland University of Technology, is gratefully acknowledged. The Australian Research Council (ARC) is thanked for funding the instrumentation. The authors would like to acknowledge the Center of Microscopy at the Universidade Federal de Minas Gerais (http://www.microscopia.ufmg.br) for providing the equipment and technical support for experiments involving electron microscopy. R. Scholz offers thanks to FAPEMIG - Fundação de Amparo à Pesquisa do estado de Minas Gerais (Grant No. CRA - APQ-03998-10).

\section{Appendix A. Supplementary material}

Supplementary data associated with this article can be found, in the online version, at http://dx.doi.org/10.1016/j.saa.2013.06.012.

\section{References}

[1] I.A. Sobolev, F.A. Lifanov, S.V. Stefanovskii, S.A. Dmitriev, N.D. Musatov, A.P. Kobelev, N.V. Zakharenko, Sov. Atom. Energy 69 (1991) 848-852.

[2] B.P. Tarasevich, L.B. Isaeva, E.V. Kuznetsov, I.A. Zhenzhurist, Glass Ceram. 47 (1991) 175-178.

[3] L.P. Konerskaya, R.G. Orlova, E.P. Bogdanis, V.D. Konerski, N.P. Guseva, Glass Ceram. 45 (1988) 199-201.

[4] E. Medvedovski, Int. Ceram. Rev. 45 (1996) 82-86.

[5] T.A. Sheveleva, A.D. Verkhoturov, S.V. Nikolenko, G.P. Komarova, V.V. Podlesov, A.M. Stolin, T.N. Shishkina, M.V. Inadze, Elektron. Obrab. Mater. 1 (1991) 2630.

[6] V.I. Il'in, Ogneup. Tekhniche. Keram. 9 (2003) 31-32.

[7] V.L. Zhuk, S.V. Timoofeeva, A.M. Kondratyuk, V.G. Osipov, V.V. Akulov, I.I. Bornatskii, Metallurgist 31 (1987) 88-89.

[8] Y.R. Vasil'ev, O.N. Laguta, V.G. Pavlov, A.Y. Shevko, Dokl. Akad. Nauk. 348 (1996) 644-646.

[9] M.H. Klaproth, J. Chem. 6 (1806) 107-110.

[10] T. Ito, H. Mori, Acta Cryst. 6 (1953) 24-32.

[11] F.F. Foit Jr., M.W. Phillips, G.V. Gibbs, Am. Mineral. 58 (1973) 909-914.

[12] Y.V. Ivanov, E.L. Belokoneva, Acta Cryst. B63 (2007) 49-55.

[13] R. Li, Z. Li, M. Mao, Y. Pan, Phys. Chem. Min. 38 (2011) 33-43.

[14] N. Perchiazzi, A.F. Gualtieri, S. Merlino, A.R. Kampf, Am. Mineral. 89 (2004) 767-776

[15] M.E. Back, J.A. Mandarino, Min. Rec. (2008).

[16] F. Zaccarini, S. Morales-Ruano, M. Scacchetti, G. Garuti, K. Heide, Chemie Der Erde - Geochem. 68 (2008) 265-277.

[17] J.G.D. Tanago, A.L. Iglesia, Estud. Geol. 54 (1998) 181-190.

[18] F. Pezzotta, V. Diella, A. Guastoni, Am. Mineral. 84 (1999) 782-789.

[19] K. Taira, H. Wada, Geosci. Rep. Shizouka Univ. 26 (1999) 39-49.

[20] J. Tarney, A.W. Nicol, G.F. Marriner, Mineral. Mag. 39 (1973) 158-175

[21] M.R. Hansen, G.K.H. Madsen, H.J. Jakobsen, J. Skibsted, J. Phys. Chem. A109 (2005) 1989-1997.

[22] V.C. Farmer, Mineralogical Society Monograph 4, The Infrared Spectra of Minerals, London, 1974. 